\title{
Mellon Institute of Industrial Research
}

$\mathrm{D}^{\mathrm{R}}$ R. E. R. WEIDLEIN, the director of the Mellon Institute for Industrial Research, Pittsburgh, has published his twenty-third Report to the trustees. The Institute, established in 1913, was the material outcome of Prof. Robert Kennedy Duncan's system of industrial fellowships started in the University of Pittsburgh two years before. Since 1911, there have been 1,085 industrial fellowships on 268 technological subjects, and more than 500 new or improved processes and products have resulted, recorded in nearly 2,000 contributions to scientific literature. The Report claims with truth that the 363 fellows and 414 assistants who, having completed their fellowships, have entered the fields of manufacture, commerce and education constitute a most valuable gift. To celebrate the silver jubilee, a new building is under construction.

In the year ended March 1, 1936, the total sum of 632,546 dollars was received by the Institute from companies and associations for the creation of fellowships to defray the cost of scientific investigations ; and the total contribution during the full period of twenty-five years is $10,662,091$ dollars.

The Report for 1935-36 under review records the production in the laboratories during the year of an opal glass, two marble products, a group of refractories, several series of organic compounds, a synthetic resin, a specialty paper, an alloy steel for safety-razor blades, and several waterproofing agents for open fabrics. Physical methods for determining the character and amount of suspended solids in the air are progressing, the spectrograph and $\mathrm{X}$-rays having been used to study ashed specimens of lungs. The Department of Research in Pure Chemistry, in co-operation with local hospitals, has investigated cinchona alkaloids, especially in relation to pneumonia. Some of these products cause serious visual trouble. Hydroxyethylapocupreine has given encouraging results. Patents have been obtained for some of these products "to ensure proper production and distribution". There is hope as the result of another research of producing anti-pneumococcic and anti-streptococcic sera.

During the calendar year 1935, 10 bulletins, 22 research reports and 58 other papers were issued from the Institute ; 34 U.S. patents and 78 foreign patents were obtained. The record for the twentyfive years is 18 books, 132 bulletins, 726 research reports, 1,081 articles, and 617 U.S. patents. These statistics afford eloquent and incontrovertible evidence of the success of the scheme of industrial fellowships and reflect great credit on its organisers.

The present writer having had the privilege of attending the birth of the Mellon Institute derives special pleasure in expressing the congratulations of NATURE on the completion of twenty-five years working of the industrial fellowship system in the University of Pittsburgh. The idea came to life so long ago as 1906, when Duncan was attending the International Congress of Applied Chemistry in Rome; a year later, he established the first industrial fellowship in the University of Kansas, and in May 1907 published particulars of the scheme in the North American Review. The work, as already stated, commenced in Pittsburgh in 1911, and two years afterwards the brothers Andrew Richard and Richard Beatty Mellon, by a gift of half a million dollars, placed it on a permanent basis.

I first heard of the scheme when visiting the Canadian universities in 1910, as a preliminary to the first Congress of the Universities of the Empire, held in London in 1912. Discussing with Prof. H. R. Lang of the University of Toronto the urgent need for establishing liaison between the universities and industry if Great Britain were to survive the coming war, whether economic or martial, I was informed of Duncan's scheme and that Duncan, himself a patriotic Canadian, had offered to establish his scheme in that University. $\mathrm{He}$ met with refusal, and Pittsburgh secured what Toronto could not accept. In 1913, as Mitchell Student of the University of London, I investigated the work under Duncan's tutelage both in the University of Kansas and the University of Pittsburgh; and published the results in a Board of Education Pamphlet (No. 30; August 1915), and in an article in the Quarterly Review (October 1915). NATURE and other scientific and lay journals gave publicity to the scheme; but, possibly owing to preoccupations of the Great War, not much interest was displayed by universities or industries.

In 1915 , the Government, recognising the urgency of the problem, published a "Scheme for the Organization and Development of Scientific and Industrial Research" which opened with the encouraging statement: "There is a strong consensus of opinion among persons engaged both in science and in industry that a special need exists at the present time for new machinery and for additional State assistance in order to promote and organise scientific research with a 
view especially to its application to trade and industry".

It was declared in the scheme that "a great part of all research will necessarily be done in Universities and Colleges". In the first report of the Committee of the Privy Council (for 1915-16), signed by the chairman, Sir William McCormick, there was a full and admirable discussion of the problem referred to the Committee, which examined with restrained enthusiasm the possibility of establishing special research institutes in universities. The time, in any event, would have been unpropitious for the adoption of the policy of promoting industrial research in uni- versities and colleges. Since the Great War, however, conditions have changed. There has been a prodigious increase in the number of university graduates capable of undertaking scientific and industrial research; a great development of industries based on science, assisted, without question, by the limitation of German and other foreign competition; and a quickened sense that science in alliance with industry must help to solve the problem of unemployment. These conditions are favourable for an experiment on the basis admirably demonstrated by the Mellon Institute of Industrial Research.

\section{T. Ll. Humberstone.}

\section{Obituary}

\section{Prof. Karl Pearson, F.R.S.}

$\mathrm{W}$ ITH Prof. Karl Pearson, who died suddenly on April 27, has passed one of the great figures of the last half-century in science. He was born in 1857, son of William Pearson, K.C., of sturdy Yorkshire stock. Educated first at University College School, he entered King's College, Cambridge, as a scholar in 1875, and took his B.A. (Mathematical Tripos, 3rd Wrangler) in 1879; he was elected a fellow of the college in the following year, and remained a fellow until 1886. In 1882 he was called to the Bar in the Inner Temple, and originally intended to make the law his profession. But Sir Alexander Kennedy persuaded him to give up law and, to use his own expression, "finally lkinded me in Clifford's chair of Applied Mathematics at University College"- the Goldsmid professorship of applied mathematics and mechanics in the University of London. This was in 1884. He was the spiritual, not the direct, successor to Clifford, who had died in 1879 ; the post had in the meantime been held by Prof. Henrici.

In this chair Pearson lectured not only in the varied subjects required by candidates for University of London degrees in arts and science, but also gave lectures to engineering students, with accompanying classes in the drawing office, on graphic methods applied to mechanies, the determination of stresses in structures and so forth. There was, I believe, no similar course held in any British engineering school at that time, except possibly by Prof. Henrici at the then Central Technical College. During these early years, Pearson completed and edited, at the request of the syndics of the Cambridge University Press, Todhunter's "History of the Theory of Elasticity" (188693 ), the request having apparently been made to him, as he stated in some recent recollections (Math. Gazette, Feb. 1936), owing to Todhunter having incorporated in his MSS. a portion of one of Pearson's papers for a Smith Prize.
Pearson had been keenly interested by the work of Francis Galton and his statistical ideas, and felt that here was a new field for mathematical treatment and advance. Measurements on crabs made by his colleague Prof. Weldon presented an initial problem, and his first statistical paper was eommunicated to the Royal Society in October 1893 under the title "Contributions to the Mathematical Theory of Evolution", words used afterwards in the altered form "Mathematical Contributions to the Theory of Evolution" as a general title to many other memoirs. This paper dealt with the problem of dissecting a frequency distribution which could be assumed to be compounded of two normal frequency curves, and is important not only for its special subject but also for the introduction of the method of moments. This was followed in December 1894 by the second memoir, "Skew Variation in Homogeneous Material", developing his now well-known system of frequency curves, and by the third in September 1895 on "Regression, Heredity and Panmixia", developing the theory of correlation with special reference to heredity.

The memoir by Pearson and Miss Alice Lee (June 1897) "On the Distribution of Frequency of Baro. metric Height, etc." forms an interlude on a practical application ; but with the fourth of the "Evolution" series (October 1897) "On the Probable Errors of Frequency Constants", written in conjunction with L. N. G. Filon, then his demonstrator but afterwards his successor in the chair, the first stage in the development of the Pearsonian corpus of statistical theory may be said to have been completedfrequency distributions, correlation, probable errors had all been given a first consideration. Truly astounding is the mass of work that followed, the more so when one remembers that it was not until 1911, when the Eugenics Record Office and its staff under Prof. Pearson's supervision had been already for some years in existence, that the will of Francis 